public interest and resort, the small exhibition of antiquities in the Prehistoric Room reopened in August last and the selection of books, manuscripts, prints and drawings in two ground-floor rooms have proved a considerable attraction for visitors from overseas and others. The exhibition in the Prehistoric Room includes models of prehistoric sites in Britain and a number of small archæological exhibits and photographs, an evolutionary series of European prehistoric tools and weapons of stone and bronze, a series of newly designed labels giving an outline of European prehistory or early history from 550,000 B.c. to the Norman conquest, a small case of Romano-British antiquities, and photographs and other illustrations of the Saxon ship-burial at Sutton Hoo. The exhibits are either duplicates or of little intrinsic value.

Members of the public and archæologists in particular will, however, receive with regret the announcement that one branch of the Museum's work hitherto carried on without modification or interruption will now cease, at least for the time being. The current number of the British Museum Quarterly $(14,4 ; 1940)$ contains an announcement that publication must now cease until after the War. The excellence of the illustrations and the scholarly character of the contributions, especially when they turned aside from description to broader issues raised by the exhibits, have won for this periodical an enduring place in the literature of the studies with which the Museum is concerned.

\section{Rationalists and Current Concepts}

The Rationalist Anndal for 1941 (London: The Rationalist Press Association, 1940, pp. 86, 1s. net) includes, as usual, a number of articles which are calculated to stimulate controversy, even though some of them may appear to have been written with a sub-intention pour épater le bourgeois. Dr. Gilbert Murray in "Why Despair of Reason ?" discusses the thesis that the modern psychologists, in diminishing the authority of reason, have played an important part in turning "a decent and humane world into an ill-managed lunatic asylum"; while Sir Peter Chalmers Mitchell in "Religion in Trouble", in citing the Union of Soviet Republics as an example of the inefficacy of prayer, expresses profound admiration for the achievement of that "new force of civilization" in education and public health. From the former as a "capacity-catcher" he looks forward to "an almost colossal contribution to the progress of mankind". In a contribution on the laws of Nature, Prof. J. B. S. Haldane expounds the modern concept of their nature and authority, noting in particular such modification as has been introduced by the recent work of Jeffreys and Milne, summing up in the conclusion that "so far from being laid down by the arbitrary word of a creator, they [natural laws] may prove to be a system as intimately and rationally knit together as the propositions of geometry, and yet changing and evolving with time like the forms of plants and animals."

Of special topical interest is the article by Sir
Arthur Keith on "Human Nature : a New Approach to its Study", in which he returns, but from rather a new point of view, to his now familiar argument of the part played by war in the evolutionary development of races and nations. Briefly, his argument here is that the hormones, being responsible for the differential development of racial (physical) characters, the reaction against contact and interference from outside which is characteristic of the group from the most primitive social stage onward, and is the motive force which lies at the root of the impulse to war, is a provision in human nature to preserve the integrity and isolation of the group as a breeding ground for the development of group or racial characters. Man's mental constitution, therefore, in Sir Arthur's view, thus becomes the 'breeder' responsible for race-building. Passing over the question whether he has not here allowed his metaphor from selective breeding to betray him into a false personification of man's mental constitution, it seems illogical that while he admits the continuous development in size and complexity of the social group within which inter-group discords and enmities are eliminated, he turns away from the conception of one single group embracing all mankind throughout which there would be no more war. Is it not possible to ask whether, if Homo sapiens is one single species, is the group struggle to perpetuate racial differences necessary to his survival ?

\section{Carnegie Corporation of New York}

THE report of the Carnegie Corporation of New York for September 30, 1940, includes the reports of the president and of the treasurer on the Main Endowment Fund and on the British Dominions and Colonies Fund. The report of the president, Mr. F. P. Keppel, points out that the Corporation has for the first time in many years incurred obligations in excess of the current income of the main endowment fund; this is due mainly to the voting of an emergency fund of 750,000 dollars for the Carnegie Institution of Washington, in addition to a grant of 150,000 dollars to make it possible for the Institution to construct a cyclotron, and to a grant of 650,000 dollars for Harvard University for the reorganization of the Dental School, but partly to the continued low interest rate. Other grants made during the year have been in the field of adult education, library interests, the arts, research and publications. Mr. Keppel points out that as yet there has been no appreciable reduction in the total supply of funds available from all sources for education and research in the United States. Steadily increasing opportunities for fundamental research are being provided by commerce and industry; funds from Federal, State and municipal sources are being maintained and probably increased.

Despite the new and compelling calls for emergency relief in the United States and abroad, a strong appeal for a good educational or social purpose has proved effective with individual donors. Mr. Keppel, however, welcomes the growing evidence of what may be termed a conservation 